\title{
Grassflies of the subfamily Chloropinae, except the tribe Chloropini and the genus Meromyza, of Finland, Karelia and the Kola Peninsula (Diptera, Cyclorrhapha, Chloropidae)
}

\author{
E. P. Nartshuk
}

Nartshuk, E. P. 1999: Grassflies of the subfamily Chloropinae (except the tribe Chloropini and the genus Meromyza) of Finland, Karelia and the Kola Peninsula (Diptera, Cyclorrhapha, Chloropidae). - Entomol. Fennica 10: 7-28.

27 species of Chloropinae are recorded from Finland, 7 of them for the first time. 14 species are recorded from Karelia and 3 from the Kola Peninsula, all for the first time. The distributions of all species in the territory investigated are mapped. The type specimens of Lasiosina parvipennis Duda are examined and a lectotype designated. A key to the genera and species of Chloropinae, except for species of the genera Chlorops and Meromyza, is given. The distribution in Finland of all species of Chloropinae, including the genera Chlorops and Meromyza, is discussed. The fauna of Chloropinae of Finland is compared with the faunas of St. Petersburg Province, Estonia and Yakutia.

Emilia P. Nartshuk, Zoological Institute, Russian Academy of Sciences, 199034 St. Petersburg, Russia.E-mail: nep@zisp.spb.su

Received 11 June 1997, accepted 24 February 1999

\section{Introduction}

This paper is the third in a series of papers on the Chloropidae of Finland and adjacent territories of Russia. It deals with the species of the subfamily Chloropinae, except the genera Meromyza Meigen, Chlorops Meigen, Melanum Becker and Epichlorops Zetterstedt, which were discussed earlier (Nartshuk 1992c, 1998). 28 species are considered in this paper, most of them previously recorded from Finland (Frey 1933, Hackman 1980), seven are new records and one further species is expected in southern Finland. Fourteen species are recorded from Karelia and only three on the Kola Peninsula, all these species being recorded for the first time from their respective territories.
Some ecological data on the Finnish Chloropinae were published by Krogerus (1932, 1960), Kontkanen (1935), Kallio (1950) and Lindberg \& Saris (1952).

\section{Material}

The present review is based on extensive material from Finland, Karelia and the Kola Peninsula deposited in the Zoological Museum of the University of Helsinki, and in the Zoological Institute of the Russian Academy of Sciences in St. Petersburg, including material collected by the author in Finland near Helsinki in 1985. Some specimens from Finland were kindly sent to me by Mr. M. Koponen (Department of Applied Zoology of Helsinki University). A total of 2,876 specimens was examined, more than 2,500 of them collected in Finland. 
The subfamily Chloropinae is characterized by the following peculiarites: costal vein ending at or just beyond $\mathrm{R} 4+5$; vein $\mathrm{R} 2+3$ ending nearly in the middle of costal edge of wing; ocellar bristles directed forward and divergent; femoral ogan absents, tibial organ presents in Thaumatomyia Zenker, Cryptonevra Lioy, Eutropha Loew, Centorisoma Becker, and in Cetema Hendel.

\section{Key to the genera and some species of Chloropinae}

1. One to three orbital bristles much longer than remainder (Fig. 1, A). Body yellow with black stripes, fused in some species on scutum 2

- All orbital bristles even in size ( Fig.1, B G). Body from yellow with black stripes on scutum to entirely black

8

2. Crossveins of wing approximated, their separation not greater than dm-cu (Fig. 2, B). Body smaller

Pseudopachychaeta Strobl - 3

- Crossveins separated by distance greater than $\mathrm{dm}$-cu. Body larger ... Lasiosina Becker - 5

3. Scutum with dusted black stripes fused. Ocellar triangle entirely darkened

P. ruficeps

- Scutum yellow with 3 black stripes distinctly separated. Ocellar triangle yellow or darkened

... 4

4. Female cerci narrower, soft and thickly pubescent (Fig. 3, A) ... P. approximatonervis

- Female cerci deeper, compressed, strongly sclerotized and with a few hairs (Fig. 3, B)

$P$. heleocharis

5. Ocellar triangle without shining rhombic spot apically. Wings usually shorter than abdomen L. parvipennis

- Ocellar triangle with shining rhombic spot apically (Fig. 1, A). Wings normal, longer than abdomen 6

6. Only one posterior notopleural bristle. First flagellomere and palpi in male yellow, in female black. Male genitalia fig. 4, E ........ L. brevisurstylata

- Two posterior notopleural bristles 7

7. Antennae black and palpi yellow in both sexes. Abdomen with white hairs, only some hairs black. Male genitalia Fig. 4, C, D .....
L. albipila

- Antennae and palpi yellow in male and black in female. Abdomen with black hairs. Male genitalia fig. 4, A, B

L. herpini

8. Posterior femur greatly enlarged (Fig. 2, y) 9

- Posterior femur not enlarged .................. 11

9. First flagellomere longer than deep. Frons produced anteriorly (Figs. 1, H, I). Veins R1 and R2+3 straight (Fig. 2, E). Body large, reddish yellow..... Platycephala Fallen - 10

- First flagellomere as long or slightly longer than deep. Frons weakly produced anteriorly. Veins R1 and R2+3 curved to costa (Fig. 2, D). Body smaller, greenish Meromyza Meigen (key to species given by Nartshuk 1992c).

10. First flagellomere longer and much narrower at tip than at base (Fig. 1, I). Frons without punctures .................... P. umbraculata

- First flagellomere shorter and slightly narrower at tip than at base (Fig. 1, H). Frons with black punctures ............ P. planifrons

11. Head trianglular in side view. Body densely covered with long setae (Fig. 1, G)

(one species - T. pubescens)

Trichieurina Meigen

- Head rectangular in side view. Body with sparse short setae .................................. 12

12. Crossveins $\mathrm{r}-\mathrm{m}$ and $\mathrm{dm}$-cu approximated, their separation not greater than dm-cu (Fig. 2, C) 13

- Crossveins r-m and dm-cu separated by distance greater than $\mathrm{dm}$ 14

13. A row of setulae on ocellar triangle inside its lateral margin (Fig. 1, B). Surface of scutum rugose and shining ... Diplotoxa Loew (one species D. messoria, male genitalia Fig. 4, I).

- Row of setulae on frons outside lateral margin of ocellar triangle (Fig. 1, C). Surface of scutum smooth, evenly dusted

(one species D. dalmatina)

Diplotoxoides Andersson

14. Ocellar triangle with one or more rows of setulae inside lateral margin (Figs. 1, D-F).

15

- No setulae inside lateral margin of ocellar triangle. Setulae sometimes present on frons 
outside ocellar triangle (as in Fig. 1, C) 22

15. Scutum yellow with black or red longitudinal stripes. Scutellum flattened, with apical bristles approximated........Thaumatomyia Zenker 16

- Scutum entirely black 20

16. Gena narrow, no more than 0.5 depth of first flagellomere; ocellar triangle with two rows of setulae inside lateral margins (Figs. 1, D, $\mathrm{K})$. Male abdomen with two lateral membranous vesicula seen usually in macerated abdomen (Fig. 3, C). T. notata

- Gena broad, as deep or deeper than first flagellomere; ocellar triangle with one row of setulae inside lateral margins (Figs. 1, E, F, $\mathrm{L}, \mathrm{M})$ 17

17. Ocellar triangle carinate in apical part; gena very deep, deeper than first flagellomere (Figs. 1, E, M) . T. trifasciata

- Ocellar triangle without carina in apical part, gena not deeper than first flagellomere (Fig. $1, \mathrm{I}, \mathrm{L})$ 18

18. Scutum and scutellum with sparse hairs. Scutum with black shining stripes, middle stripe reaching scutellum. Male abdomen with arched membranous vesicula seen best in the macerated abdomen (Figs. 3, D, E)

T. glabra

- Scutum and scutellum distinctly haired. Scutum with black or red stripes, middle stripe usually ending before scutellum. Male abdomen without membranous vesicula. .. 19

19. Body yellow with black or red stripes on scutum T. rufa

- Body darkened with black stripes. Male genitalia fig. 3, F..... T. hallandica

20. First flagellomere of antennae rounded apically .................... Neohaplegis Beschovski (one species - N. tarsata, male genitalia fig. $4, \mathrm{G})$.

- First flagellomere of antennae acuminate . Cryptonevra Lioy - 21

21. Frons yellow in front. Male genitalia fig. 4 , $\mathrm{H}$ C. diadema

- Frons entirely black C. flavitarsis

22. Arista shorter than remainder of antenna, nearly bare. Setulae of body white Eutropha Loew - 23

- Arista equal to or longer than remainder of antenna. Setulae of body usually black . 24

23. Pleura and scutellum yellow. Scutum with grey dusted stripes fused in some specimens

E. variegata

- Thorax and abdomen black, shining. Only sides of scutum a little dusted E. fulvifrons

24. First flagellomere longer than deep. Arista white 25

- First flagellomere as long as deep. Arista black or white 26

25. Scutum black and rugose

Centorisoma Becker (one species - C. elegantulum).

- Scutum yellow, smooth, with 5 pollinose dull black stripes, lateral stripes with velvet black spot anteriorly ...... Parectecephala Becker (one species P. longicornis Fallén)

26. Scutum yellow with black or red longitudinal stripes .......... Chlorops Meigen (part). (key to species given by Nartshuk, 1998).

- Scutum black, at most postpronotum and notopleuron partly yellow..................... 27

27. Surface of scutum smooth .................... 28

- Surface of scutum rugose ....................... 29

28. Vibrissal angle acute (Fig. 1, J)

(one species - $M$. laterale Haliday)

- Vibrissal angle obtuse Chlorops Meigen (part)

(key to species given by Nartshuk, 1998)

29. Ocellar triangle reaching anterior margin of frons. Middle tibia with small apical spur.

Epichlorops Zetterstedt (one species - E. puncticollis Zetterstedt).

- Ocellar triangle not reaching anterior margin of frons. Middle tibia with strong apical spur................Cetema Hendel ....... 30

30. Arista white. Anterior and middle tibiae of male with long hairs (Fig. 2, F). Male genitalia fig. 3, G C. cereris

- Arista black. Anterior and middle tibiae of male with or without long hairs 31

31. Anterior and middle tibiae of male without long hairs. Epandrium of male genitalia with straight processes (Figs. 3, H, J) .......... 32

- Anterior and middle tibiae of male with long hairs (as in fig. 2, F) 33

32. Genitalia of male figs $3, \mathrm{H}, \mathrm{I}$. Processes short- 

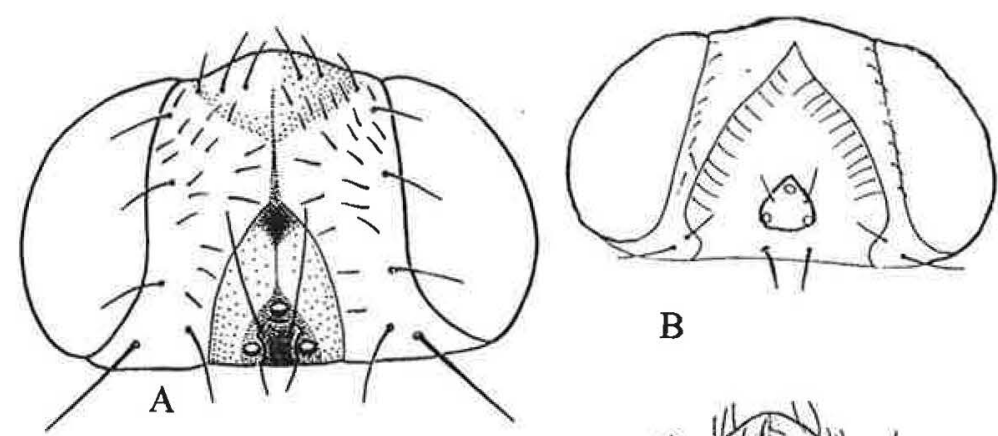

B

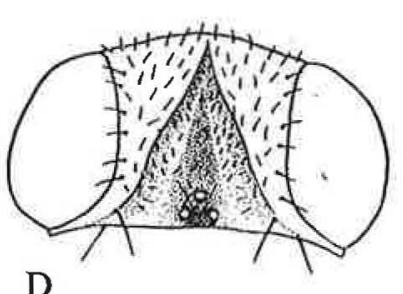

$\mathrm{D}$
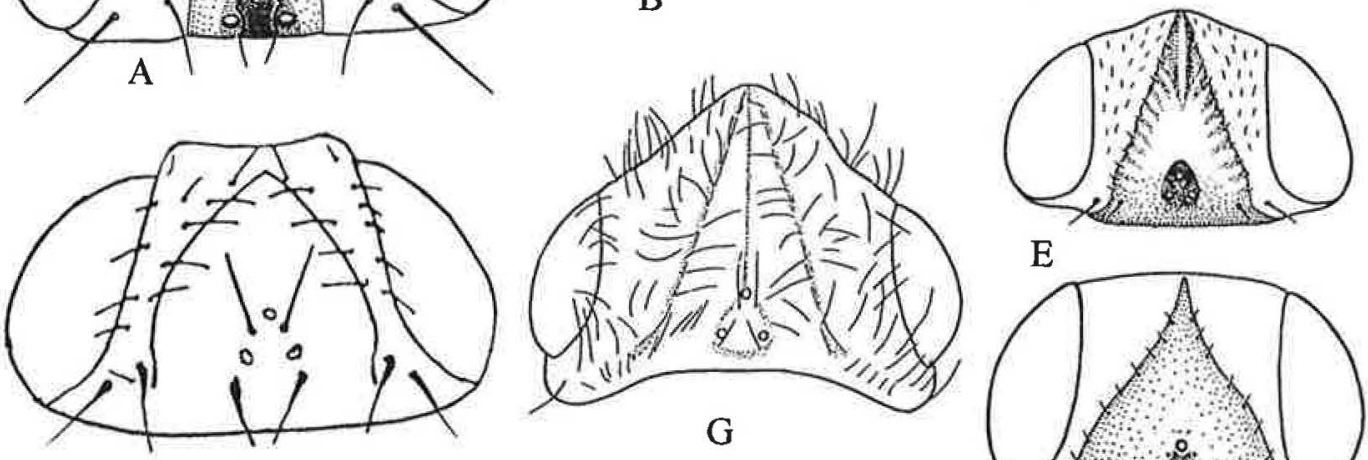

C

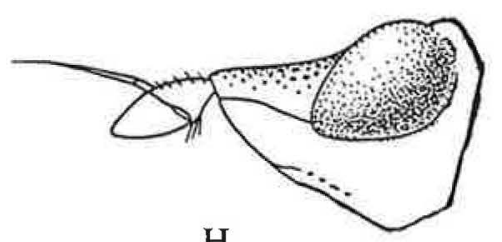

$\mathrm{H}$

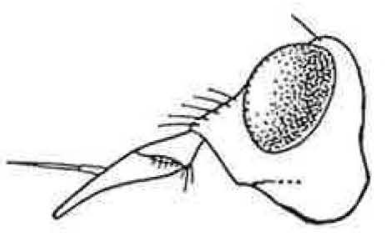

I
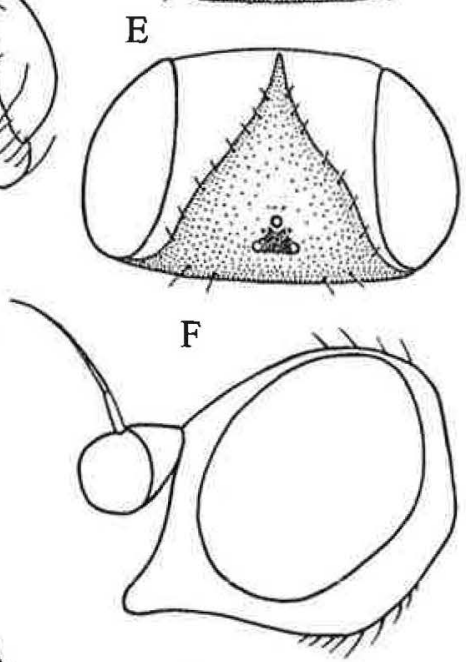

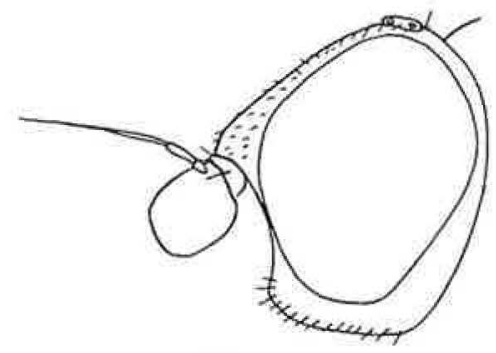

K

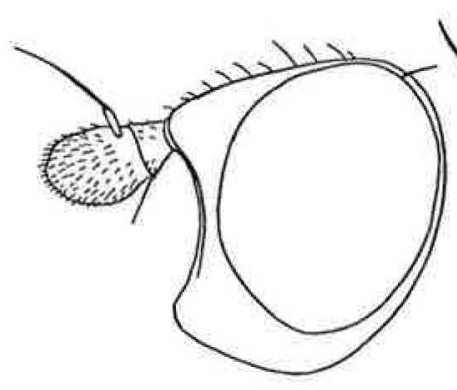

$\mathrm{L}$

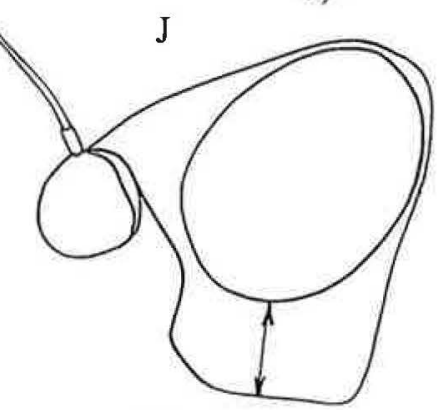

M

Fig. 1. Heads of Chloropinae: A - Lasiosina herpini; B - Diplotoxa messoria; $C$ - Diplotoxoides dalmatina; $D$ - Thaumatomyia notata; $E$ - T. trifasciata; $F$ - T. rufa; $G$ - Trichieurina pubescens; $H$ - Platycephala planifrons; $I$ - $P$. umbraculata; $J$ - Melanum laterale; $K$ - Thaumatomyia notata; $L$ - T. hallandica; $M-T$. trifasciata (arrows show breath of genae). 

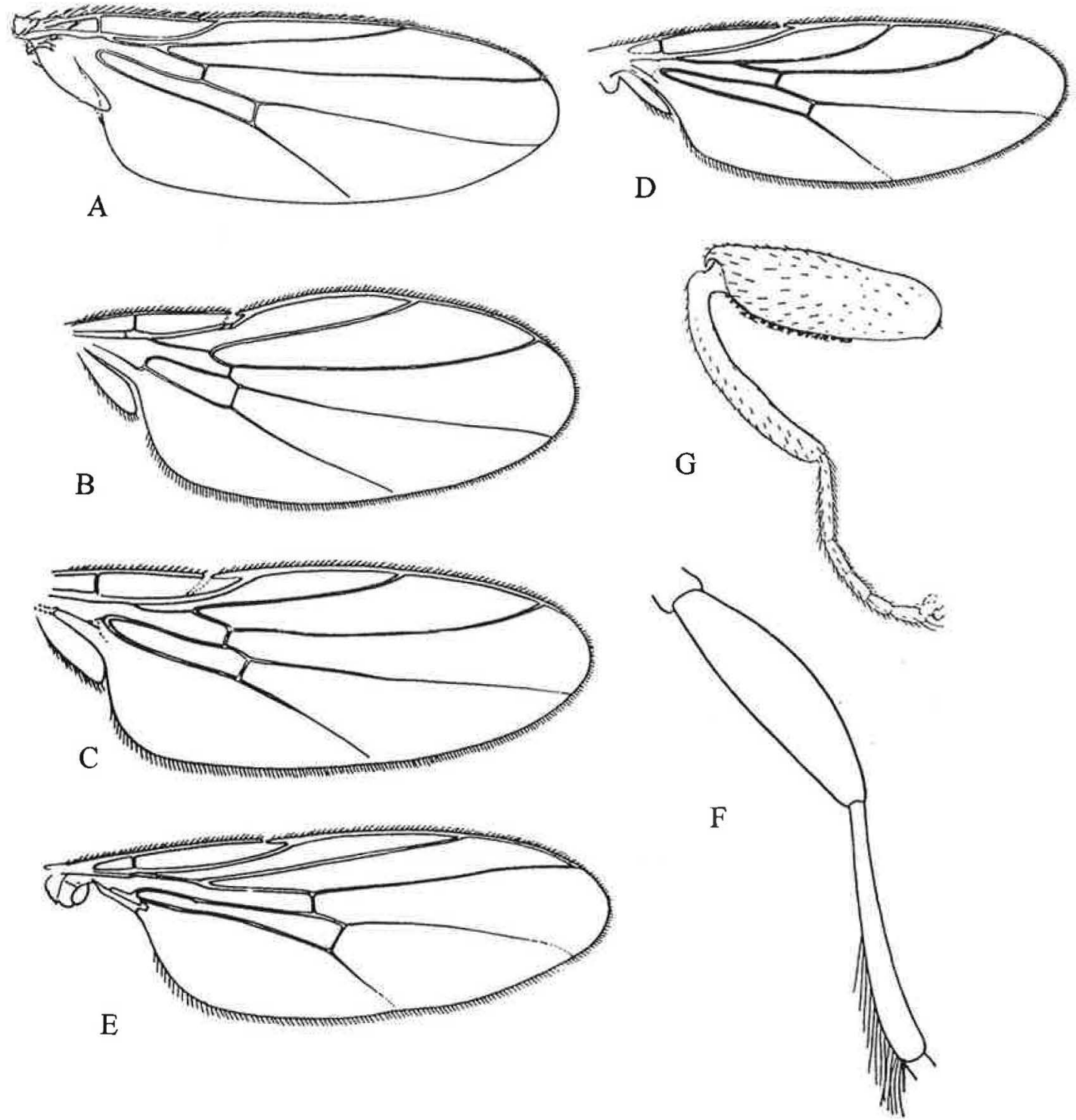

Fig. 2. Wings and legs of Chloropinae: $A$ - Chlorops sp.; $B$ - Pseudopachychaeta heleocharis; $C$ - Diplotoxa messoria; $D$ - Meromyza sp.; $E$ - Platycephala planifrons; F - Cetema cereris; male middle leg; $G$ - Meromyza sp, hind by. 


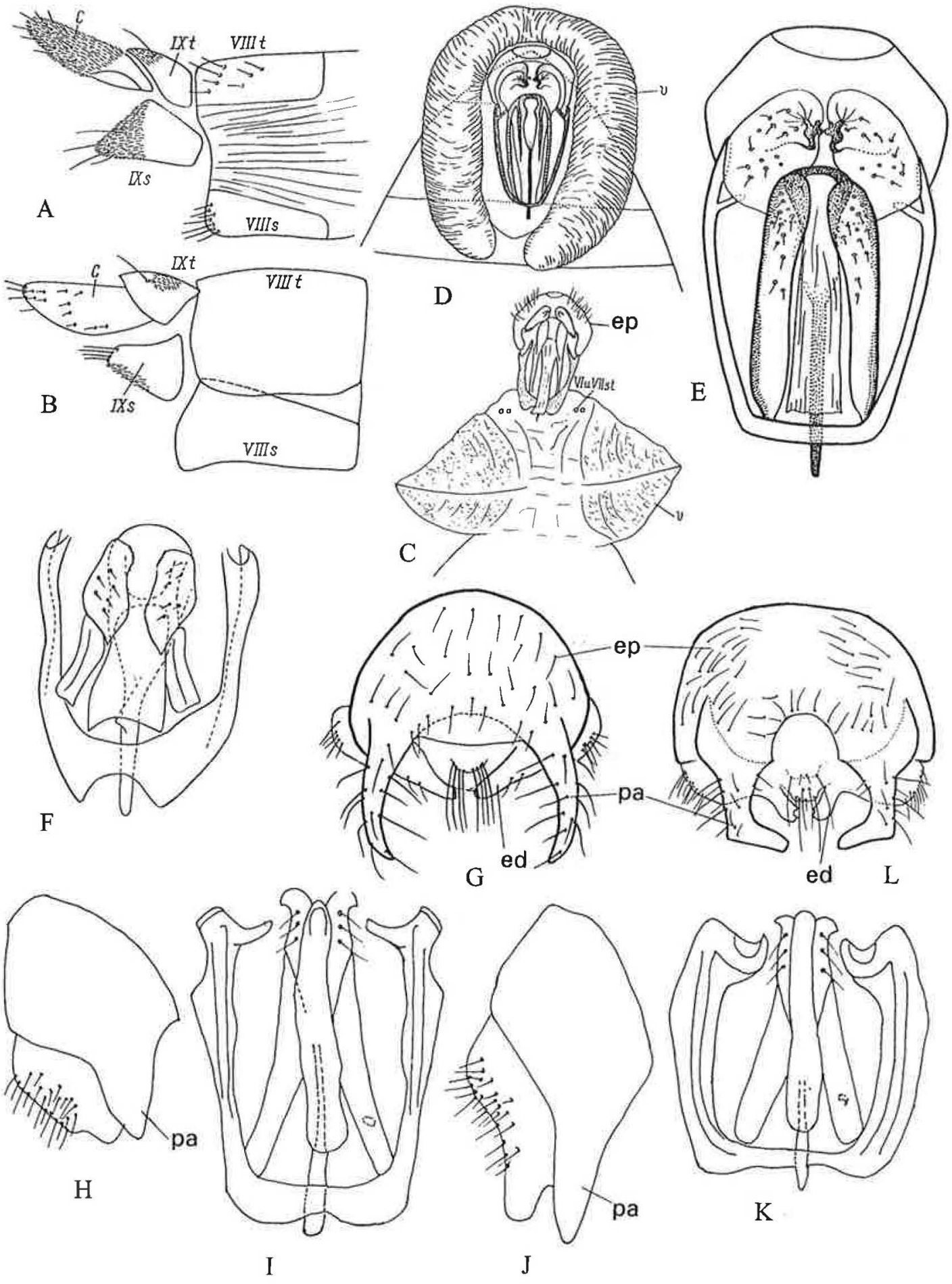

Fig. 3. Male and female terminalia of Chloropinae: $A$ - Pseudopachychaeta approximatonervis; $B$ - P. heleocharis; $C$ - Thaumatomyia notata; D, E - T. glabra; F - T. hallandica; G - Cetema cereris; H, I - C. elongatum; J, K - C. simile; $L$ - C. myopinum; $F$ - after Andersson, 1977. ed - surstyli, ep - epandrium, pa - additional process, s - sternite, st stigma, $\mathrm{t}$ - tergite, $\mathrm{v}$ - membranous vesicula. 


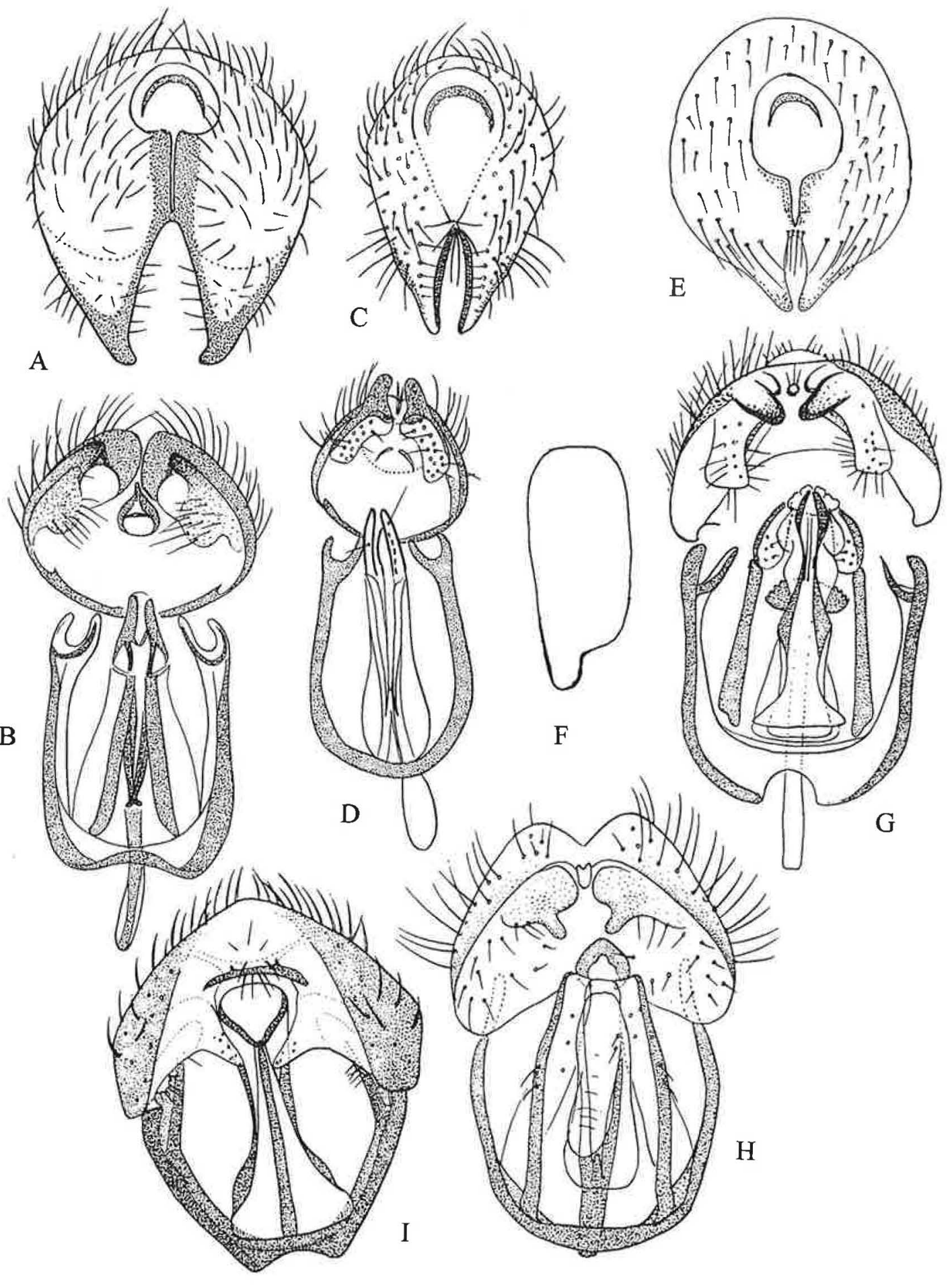

Fig. 4. Male terminalia of Chloropinae: $A, B$ - Lasiosina herpini; $C, D-L$. albipila; $E$ - $L$. brevisurstylata; $F$ - $L$. parvipennis (lectotype, dry specimen); $G$ - Neohaplegis tarsata; $H$ - Cryptonevra diadema; I - Diplotoxa messoria. 
er with oblique end, hypandrial arms slender C. elongatum

- Genitalia of male fig. 3, J, K. Processes longer and tapering, hypandrial arms more massive . C. simile

33. Male genitalia with straight processes (as in fig. 3, G, H) C. neglectum

- Male genitalia with processes curved mesad (Fig. 3, L) C. myopinum

\section{List of the species, found in Finland, Karelia (Kr) and the Kola Peninsula (= Murmansk oblast, Lr)}

The abbreviation of the biological provinces in Finland are used according to the series Fauna entomologica scandinavica. There is no Finnish material reared from plants available, but hostplants are mentioned for some species on observationon other parts of the Palaearctic.

\section{Platycephala planifrons (Fabricius, 1798).}

Finland. Al: Lemland, Geta, Finström, Jomala, Eckerö, Föglö Bano, Kökar. Ab: Dragsfjärd, Lohja, Naantali, Nagu, Särkisalo, Bromarv, Kaarina, Runsala, Pargas, Uusikaupunki. $N$ : Tvärminne, Karjalohja, Sammatti, Tammisaari, Hanko, Inkoo, Helsinki, Sveaborg, Porvoo. St: Yläne. Ta: Heinola, Hauho. Sa: Mikkeli. Kl: Parikkala. Kb: Pyhäselkä. Om: Pietarsaari. $O b$ : Hailuoto, Liminka. Total 220 specimens.

Russia. Kr: Jakkima, Salmi, Shuya. Total 5 specimens.

Adults in June - August, in southern Finland also in the first half of September. Found almost everywhere common reed (Phragmites australis) grows. The larvae develop in stems of reed. Recorded northwards to Oulu.

Europe, North Africa, Transcaucasus, Kazakhstan.

\section{Platycephala umbraculata (Fabricius, 1794).}

Finland. $A l$ : Eckerö. $A b$ : Kuusto, Parainen. $N$ : Nurmijärvi. $O m$ : Pietarsaari. Total 59 specimens.

Adults in July and August. The larvae develop in stems of Phragmites australis. It is less abundant than the preceding species and occurs only in the south-western part of Finland.

A transpalaearctic species, from Great Britain to the Far East.

\section{Trichieurina pubescens (Meigen, 1830).}

Finland. $K b$ : Pyhäselkä (Hammaslahti), 15.06. 1935, 4.06.1938, 7.07.1939, Kontkanen, $1 \sigma^{7}, 5 \%$ \%

The species occurs only on bogs and the hostplant is unknown, supposedly sedges. Kontkanen (1935) described in detail the locality. The species is probably distributed more widely in Finland.

Europe, Transcaucasus, Kazakhstan.

\section{Cryptonevra diadema (Meigen, 1830).}

Finland. $A l$ : Lumparland, Finnström, Geta, Kökar, Marianhamn. $A b$ : Naantali, Karjaa, Turku, Västanfjärd. $N$ : Helsinki, Tvärminne. Oa: Vasklot, Korsholm. Om: Pietarsaari. Total 26 specimens.

Adults in June and July. The larvae live in stems of Phragmites australis, mostly as inquilines in Lipara galls. It is less abundant than C. flavitarsis and occurs only in the south-western part of Finland. It has not been previously recorded from St. Petersburg Province (Stackelberg, 1956), but I found it in 1989 at Myaglovo, $20 \mathrm{~km}$ east of St. Petersburg. The specimens were bred from Lipara galls.

From Europe to Japan, North Africa.

\section{Cryptonevra flavitarsis (Meigen, 1830).}

Finland. Al: Föglö Bano, Geta, Sund, Finström. $A b$ : Uusikaupunki, Parainen, Nagu, Turku, Västanfjärd. $N$ : Helsinki, Tvärminne, Porvoo, Sipoo, Inkoo. Ka: Virolathi, Kymi. Ta: Kangasala, Hattula, Hameenlinna, Urjala. Oa: Vaasa. Om: Pietarsaari, Vimpele. Total 76 specimens.

Adults in June and July. The larvae are found in stems of Phragmites australis as inquilines in Lipara galls, many larvae developing in one gall. A common species on reed. Northwards to Pietarsaari.

Europe, North Africa, Asia to Mongolia and China.

The species was omitted from the last Finnish Check-list (Hackman, 1980) but it was included in earlier lists (Frey, 1933, 1941).

\section{Neohaplegis tarsata (Fallén, 1820).}

Finland. $A l$ : Finnström. Hammarland, Jomala, Saltvik. $A b$ : Karjalohja, Salo, Pohja, Sammatti, Lohja, Pemiö. N: Täck- 
trom, Hanko, Porvoo, Tvärminne, Kirkkonummi. Ta: Hameenlinna, Pirkkala, Tampere, Janakkala, Sysmä. Sa: Mänthyharju. Oa: Korsholm. Om: Pietarsaari. Total 80 specimens.

Russia. $K r$ : Impilahti, 1 우.

Adults in June and July. The larvae supposedly live in shoots of Carex. Recorded northwards to Pietarsaari.

Europe, Transcaucasus, Kazakhstan, West and East Siberia.

\section{Cetema cereris (Fallén, 1810).}

Finland. Al: Hammarland, Eckerö, Jomala, Föglö, Kumlinge. $A b$ : Parainen, Uusikaupunki, Lohja, Karjalohja, Kaarina. $N$ : Helsinki, Espoo, Porvoo, Kirkkonummi, Hanko, Nurmijärvi, Nummela. Ka: Hamina, Vehkalahti. St: Vammala. Ta: Tampere, Sysmä, Hämeelinna, Sääksmäki. Sa: Mikkeli, Rajala Saima Kanal. Oa: Vaasa, Narpes. Tb: Jyväskylä, Viitasaari, Ähtäri, Keuruu. $S b$ : lisalmi, Kiuruvesi. $K b$ : Ilomantsi. $O m$ : Pietarsaari. $O k$ : Suomussalmi. $O b$ : Rovaniemi, Piisavaara, naturpark, Pudasjärvi. Ks: Kuusamo. Li: Utsjoki. Total 38 o응, 41 우우.

Russia. Kr: Kolatselga, Paanajärvi, Island Bolshoi Klimenezky, 2 km N Vorobji. Total $3 \sigma^{\star} \sigma^{*}$. Lr: Murmansk, $1 \sigma^{*}$

Adults from the end of July to August. A common species on wet meadows. The larvae are phytophagous, supposedly in shoots of Agrostis sp. and probably in other meadow grasses. It is found throughout Finland.

A transpalaearctic species, from Great Britain to Sakhalin.

\section{Cetema elongatum (Meigen, 1830).}

Finland. N: Espoo, 12.07. 1985, ơ (Nartshuk). Sa: Taipalsaari, $1 \sigma^{*}$ (Maklin). Females of this and the next species are indistinguishable.

A rare species, on wet meadows. Most earlier records in the literature are of $C$. simile. The larvae are phytophagous in shoots of meadow grasses. Found only in the southern part of Finland.

A European species.

\section{Cetema simile Ismay, 1985.}

Finland. $A b$ : Korpoo, Karjalohja. N: Huopalahti, Espoo, Lakisto. Ta: Tampere. Sb: Maaninka. Om: Pietarsaari. Total $140^{*} 0^{*}$.

A new species for Finland.

Found northwards to Pietarsaari.

Russia. Kr: Sortavala, Vidlitza. Total $20^{*} o^{x}$.
Adults in July - August. A more common and abundant species on meadows and usually in drier places than the preceeding species. The larvae are phytophagous in shoots of many meadow grasses.

A European species.

\section{Cetema myopinum (Loew, 1866).}

Finland. $A b$ : Kaarina. $N$ : Espoo. $K a$ : Vehkalahti. St: Yläne. Ta: Hameenlinna. Sa: Joutseno, Rajala Saima Kanal. Oa: Töysä. Sb: Maaninka. Om: Pietarsaari. Total $19 \sigma^{\circ} \sigma^{*}$.

Russia. Kr: Island Valaam, Derevyannoe. Segezha, Kostomuksha. Total $4 \sigma^{\circ} \sigma^{\circ}$.

Adults in July. It is less abundant than the preceding two species of the genus. The larvae are phytophagous in shoots of grasses. Found northwards to Vaasa.

Distributed from Europe to West Siberia and Mongolia.

\section{Cetema neglectum Tonnoir, 1921.}

Finland. Al: Saltvik, Jomala, Vårdö, Dragsfjärd. Ab: Karjalohja, Turku, Kaarina, Nauvo. N: Tammisaari, Tvärminne, Ekenäs. Sa: Mäntyharju. Total $90^{\circ} \sigma^{*}, 4 \% q$.

A new species for Finland.

Adults in July and August. It is uncommon on meadows. The species is new to Finland. It was found only in southern Finland.

A European species.

\section{Thaumatomyia glabra (Meigen, 1830).}

Finland. $A l$ : Föglö Bano, Äppelö, Finström. $A b$ : Korpoo, Karjalohja, Nauvo, Dragsfjärd, Tenala, Kaarina, Salo. $N$ : Hanko, Tvärminne, Tammisaari, Nurmijärvi, Espoo, Kirkkonummi, Helsinki, Sveaborg. Ka: Vehkalahti. St: Luvia, Pori. Ta: Tampere, Hattula, Sysmä, Teisko. Sa: Juva, Mikkeli, Savonlinna. $O a$ : Bergö, Mustasaari, Replot. $T b$ : Viitasaari. $K b$ : Liperi. Om: Vimpeli, Pietarsaari. $O b$ : Rovaniemi, Hailuoto, Simo. Lk: Muonio, Kolari. Le: Enontekiö, Siilasjärvi. Total 123 specimens.

Russia. Kr: Segezha, Konchozero, Petrosavodsk. Total 4 specimens. Lr: Gavrilovo, 1 \%.

Adults from June to September. The larvae are found in the ground and are carnivorous, feeding on root aphids. A common species. Found northwards to the Kola Peninsula.

A Holarctic species. 


\section{Thaumatomyia hallandica Andersson, 1966.}

Finland. Al: Jomala, Finström, Saltvik. $A b$ : Turku, Lemu, Nauvo, Karjalohja, Uusikaupunki, Sammatti, Tenala. N: Tvärminne, Lakisto, Nurmijärvi, Kirkkonummi, Helsinki, Hanko. St: Eura, Ka: Ylämaa. Ta: Tampere. Sa: Joutseno, Lappeenranta. Kl: Parikkala. Ob: Simo. Le: Enontekiö. Total 43 specimens.

Russia. Kr: Konchozero, Sheltozero, Chupa, Kartesh. Total 6 specimens.

Adults from June to August. The larvae are found in the ground and are carnivorous, feeding on root aphids. An uncommon species found in the whole territory of Finland.

Europe, Transcaucasus, Central Asia, West and East Siberia, Mongolia.

\section{Thaumatomyia notata (Meigen, 1830).}

Finland. Al: Sund, Marienhamn, Hammarland, Jomala, Finström. Ab: Nauvo, Uusikaupunki, Uskela, Vihti, Kiikala, Lohja, Turku, Parainen, Sammatti, Karjalohja. N: Hanko, Tvärminne, Tuusula, Espoo, Kirkkonummi, Ekenäs, Inkoo, Helsinki, Kauniainen, Sipoo, Porvoo. Ka: Vehkalahti, Heinijoki. St: Yläne. Ta: Ylöjärvi, Hattula, Jämsä, Pirkkala, Tampere, Kangasala, Sysmä, Teisko, Hämeenlinna. Sa: Taipalsaari, Mikkeli, Punkaharju, Joutseno, Ristiina. Oa: Petalax. Tb: Keuruu, Ähtäri. Sb: Kangaslampi. Om: Pietarsaari, Nykarleby, Alajärvi. Total 203 specimens.

Russia. Kr: Petrosavodsk, Salmi, Sortavala, Paanajärvi. Total 5 specimens.

Adults from May to September, hibernating. The larvae are found in the ground and are carnivorous, feeding on root aphids. A common species, especially in southern Finland. Found northwards to Vaasa.

A widespread species, in the Palaearctic, Oriental and Afrotropical Regions.

\section{Thaumatomyia rufa (Macquart, 1835).}

Finland. Al: Föglö Bano, Eckerö, Marienhamn, Finström. Ab: Turku, Kustavi, Karjalohja, Vihti, Karjaa, Parainen. N: Kirkkonummi, Nurmijärvi, Helsinki, Lakisto, Sipoo. Ka: Hamina. Ta: Jämsä, Kangasala, Parikkala, Tampere, Hauho. Sa: Joutseno, Mikkeli. Kl: Parikkala. Oa: Lapua, Lapväärtti. Tb: Ähtäri, Viitasaari. $S b$ : Tuovilahti. $K b$ : Eno, Kontilahti. $O m$ : Pietarsaari. Total 69 specimens.

Russia. Kr: Kolatselga, Petrosavodsk, Sortavala, Konchozero, Salmi, Soroka, Shuya. Total 7 specimens.

Adults from the end of June to August. The larvae are found in the ground and are carnivorous, feeding on root aphids. Finnish specimens are markedly variable in colour. The ocellar tri- angle and first flagellomere vary from almost yellow to black. Recorded northwards to Vaasa.

A transpalaearctic species, from Europe to Japan.

\section{Thaumatomyia trifasciata (Zetterstedt, 1848).}

Finland: $A l$ : Hammarland. $A b$ : Salo, Karjalohja, Korpo Jurmo, Nagu, Pargas. $N$ : Tvärminne, Nurmijärvi, Hyvinkää, Kirkkonummi, Helsinki, Espoo, Hanko. Ka: Virolahti. Ta: Hameenlinna, Pälkäne, Lammi, Kangasala. Sa: Taipalsaari, Mäntyharju, Joutseno, Valkeala, Anttola. Oa: Lapua, Lapvaartti. $T b$ : Ähtäri. $K b$ : Katiolahti, Ilomantsi. Om: Pietarsaari, Pyhäntä, Nykarleby, Pyhäjärvi. $O k$ : Suomussalmi. $O b$ : Oulu, Pisavaara naturpark, Hailuoto. Ks: Salla, Kuusamo. Lk: Muonio, Kittila. Le: Malla, Enontekiä, Kilpisjärvi. $L i$ : Utsjoki, Inari. Total 90 specimens.

Russia. Kr: Olonetz, Kartesh, Podlakhty, Chupa, Paanajärvi, Segozero, Salmi, Petrosavodsk. Total 211 sp. Lr: Trifona; Bjaloguba, Kandalaksha, Gavrilovo, Voronje, Polarny, Murmansk, Kola, Kuolajärvi, Ponoj, 50 km W Ylatuloma, Pechenga, Lutta, Kuvernoori, Khibiny Lake Vudjavr; Tuba Guba, Vioremi, Monchegorsk, Kolvitza, Tumannyi 120 km E Murmansk, Yuksporrijok River near Kirovsk, Seyidozero 20 km SE Revda. Total 67 specimens.

Adults in June - August. A common species on bogs and the supralittoral zone of the sea. The larvae are found in the ground and are carnivorous, feeding on root aphids. Recorded northwards to the sea shore of the Kola Peninsula.

A Holarctic species.

\section{Eutropha fulvifrons (Haliday, 1833).}

Finland. $N$ : Hanko, 25.07.1927 (Krogerus), 10 A new species for Finland. The species occurs on sandy places, usually on dunes on sea shores. Only in the south of Finland.

A European-mediterranean species.

\section{Eutropha variegata (Loew, 1866).}

Finland. $A b$ : Vihti, Tvärminne, Hanko.Total $3 \delta^{\circ} \sigma^{\circ}, 12$ \% 9 .

A rare species, occuring only on the sea shore on sand dunes in July and August. It is peculiar in the sexual dimorphism of the antennae: the first flagellomere is larger and yellow in males, smaller and black in females. The species is found only in southern Finland.

Recorded from Europe, Transcaucasus, Kazakhstan, Central Asia. 
Centorisoma elegantulum Becker, 1910.

The species has not been found in Finland. The nearest locality is the Island Berezovy near Vyborg, close to the Finnish border (Nartshuk, 1984). It is expected that the species will be found in southern Finland.

Known from Europe, Transcaucasus, Kazakhstan, south of West Siberia.

\section{Diplotoxa messoria (Fallén, 1820).}

Finland. Al: Geta, Jomala, Hammarland, Eckerö, Föglö Bano, Saltvik, Kökar, Marienhamn. $A b$ : Parainen, Korppoo, Turku, Kaarina, Karjalohja, Bromarv, Vihti, Nauvo, Lohja, Dragsfjärd, Uusikaupunki, Pohja. N: Tvärminne, Hanko, Ekenas, Porvoo, Sipoo, Helsinki. Ta: Hämeenlinna, Sysmä, Tampere, Kangasala. Kl: Parikkala. Oa: Vaasa, Malax, Petalax, Kristiinankaupunki, Mustasaari. $T b$ : Keuruu, Jyväskylä. $S b$ : Kiuruvesi. Kb: Ilomantsi. Om: Merijärvi, Nykarleby, Kalajoki, Pietarsaari, Larsmo. Ob: Kuivaniemi, Oulu, Hailuoto. Total 352 specimens.

Russia. Kr: Jakkima, Sortavala. Total 2 specimens.

Adults from the end of June to August. A common and abundant species in moist habitats on Eleocharis, which is its host plant. Northwards to Oulu.

A Holarctic species.

\section{Diplotoxoides dalmatinus (Strobl, 1900).}

Finland. N: Hanko, Lohja, Helsinki. Om: Pictarsaari, Uusikaarlepyy. Total $7 \delta^{\star}, 17$ 우.

Russia. Kr: Bolshie Gory, 1 \% .

Adults in July and August, in moist localities. Found northwards to Vaasa.

A transpalaearctic species, found from Europe to the Far East.

\section{Pseudopachychaeta approximatonervis (Zetter- stedt, 1848).}

Finland. Al: Saltvik, Hammarland, Lemland. Ab: Lohja, Salo, Uusikaupunki, Parainen, Pohja. N: Tvärminne, Helsinki, Hanko. Ta: Tampere, Ylöjärvi. Oa: Kverlax, Maxmo. $S b$ : Leppävirta. Om: Pietarsaari, Nykarleby. Ob: Pudasjärvi. Le: Enontekiö. Total $330^{\circ} 0^{\star}, 41$ 우요.

Adults from the end of May to June. The larvae are phytophagous, in inflorescences of species of Eriophorum, except E. vaginatum (Nartshuk, 1962). It is found throughout Finland.
A Holarctic species.

\section{Pseudopachychaeta heleocharis (Nartshuk, 1964).}

Finland. Ta: Tampere, Sysmä. Om: Pietarsaari. Total $4 q q$.

A new species for Finland, specimens from Ta were determined by O. Duda (Frey, 1933) as $P$. approximatonervis. Adults in August in wet places on Eleocharis sp., the larvae develop within inflorescences of Eleocharis. Only found in the south of Finland.

The species has been recorded previously from Europe and Northern Kazakhstan.

\section{Pseudopachychaeta ruficeps (Zetterstedt, 1848).}

Finland. $A b$ : Sammati, Lohja, Karjalohja. $N$ : Helsinki, Tvärminne, Espoo, Hanko. Ta: Lammi. Sa: Mikkeli. Oa: Vaasa, Koivulahti. Tb: Laukaa, Ähtäri, Jyväskylä. Sb: Leppavirta, Nilsia. Om: Nykarleby, Pietarsaari. Ok: Kajaani. $O b$ : Hailuoto, Pisavaara naturpark. Ks: Kuusamo. $L k$ : Muonio Kittilä, Inari. Le: Malla. Li: Utsjoki. Total $560^{\star} 0^{\star}, 52$ 우 ㅇ.

Russia. Kr: Paanajärvi, I E. Lr: Bjaloguba, Kola, Ponoj, Kuolajärvi, Kandalaksha, Trifona, Polarny, Khibiny, Lake Vydjärv. Total $110^{\star} 0^{\star}, 7$ 우.

A new species for Finland. Adults from May to September on bogs, hibernating. The larvae live in inflorescences of Eriophorum vaginatum (Nartshuk,1962). It is an abundant species on bogs. Found northwards to the Kola Peninsula.

A transpalaearctic boreal species.

\section{Lasiosina albipila (Loew, 1866).}

Finland. $N$ : Helsinki, $10^{*}$.

A new species for Finland occuring only in the south of the country.

A European species.

Lasiosina brevisurstylata Dely-Draskovits, 1977.

Finland. St: Eura, 16. 06. 1982, Koponen, 1 \% .

A new species for Finland occuring only in the south of Finland.The species was reared from shoots of winter wheat and spring barley together with $L$. herpini (as L. cinctipes) in Bulgaria (Beschovsky, Krusteva, 1997).

A Euro-Caucasian species. 
Lasiosina herpini (Guerin-Meneville, 1843) (= cinctipes auct., not Meigen, 1830).

Finland. $A b$ : Kaarina, Turku, Parainen. $N$ : Nurmijärvi, Helsinki, Vantaa. St: Vammala. Total $3 \sigma^{\circ} \delta^{\circ}, 5$ 우 ㅇ.

Russia. Kr: Kolatselga, Gizhino, Gumbartzy. Total $10^{\circ}$, 2 우 우 specimens.

Adults in July - September. It is found only in the south of Finland. The species (as $L$. cinctipes) was recorded as a pest of cereals in Finland (Kallio, 1950).

A transpalaearctic species.

\section{Lasiosina parvipennis Duda, 1933.}

Finland. $A b$ : Bromarv. St: Yläne. Ta: Pälkäne.Sa: Lappeenranta. $K b$ : Pyhaselka. Om: Nykarleby. Total $5 d^{\star} \sigma^{\star}, 3 q \circ$.

A rare species in collections because of its habits. It occurs on bogs. Specimens were captured in May and in the beginning of September. The species has shortened wings of variable length, some females having nearly normal wings. Most examined specimens are dark, with the black pubescent stripes on scutum almost fused. Found northwards to Vaasa.

The species was described from 3 specimens: $10^{7}$, "Yläne, J. Sahlberg, 142, N 8153"; $10^{*}$, "Lappvesi, J. Sahlberg, 373, N 8152" and $1 \%$ "Fl[uss] Swir, J. Sahlberg, 79". The first two specimens were collected in Finland, the third one in the eastern part of St. Petersburg Province. Two males are in the Zoological Museum of Helsinki University, but the female was not found in the collection. Both males are in good condition, fitting the original description. The male genitalia are well illustrated in the specimen from Yläne (Fig. $3, F)$ and this specimen is designated as lectotype.

Found in northern Europe, West and East Siberia, Mongolia.

\section{Distribution of the species}

The investigated territory is of special interest because the northern limits of many species are situated here. The species of the subfamily Chloropinae are mostly phytophagous. They are associated with grasses and sedges in the larval stage. Larvae live within shoots of living plants or rarely within inflorescences (Pseudopachychaeta Strobl). Species of Lasiosina Becker and Diplotoxa Loew seem to live in dead shoots, and species of Thaumatomyia Zenker are carnivorous, living in the ground and feeding on root aphids. The total number of species in the subfamily Chloropinae for Finland is 67, but for the Kola Peninsula only 13. The fauna of Karelia has not been adequately studied. The fauna of Chloropinae of the St. Petersburg Province of Russia and Estonia situated to the south of Finland has been rather well studied and 69 species are known from the St. Petersburg Province (Stackelberg, 1958, 1965, Nartshuk, 1962 and new data) and 68 from Estonia (Nartshuk, Elberg, 1979 and new data).

The number of species of Chloropinae changes insignificantly on the East European plain. It decreases by $17.6 \%$ between $50-60$ N.L., from the south of Ukraine (86 species, Nartshuk, 1992) to St. Petersburg Province ( 69 species), i.e. by about 1-1.5 species for every latitude degree. North of 60 N.L. the decrease becomes more sharp. On the next 10 degrees, between 60 and 70 N.L., the number of species decreases by $78.7 \%$, from the south of Finland ( 67 species) to the north of the country (14 species), i.e. by 5 species for one degree.

The number of species in the territory of St. Petersburg Province from the south (Luga District) to the north (the Karelian Isthmus) and to the south of Finland also changes. Only Chlorops pannonicus Strobl, C. riparius Smirnov and C. fasciatus Meigen are known from the southern part of St. Petersburg Province (Luga District) but are not found in Finland. It is worthy of note that some European species (Chlorops distinguendus Frey, C. centromaculatus Duda, Eutrophafulvifrons Haliday, Meromyza rostrata Hubicka, and $M$. elbergi Fedoseeva) are found in south-western Finland, but not in St. Petersburg Province and only the last species is recorded from Estonia. The records from Finland are the most northeastern for these species. Chlorops serenus Loew is recorded only in the south of St. Petersburg Province and found again in south-western Finland on the Aland Islands. The influence of the sea also explains the more northern distribution of many species along the coastline compared to the eastern part of Finland. 
The number of species decreases gradually from the south of Finland to the north. Some species (13) occur only in the southern part of Finland and are not found north of 61 N.L. (see maps). This boundary approximately corresponds to the isopleth 1200 (Laaksonen, 1979). The next boundary lies nearly at 63 N.L., approximately corresponding to isopleth 1100: another 10 species are not known north of this boundary. The third boundary lies at nearly 65 N.L. (the level of Oulu, isopleth 1000). Only 21 species are recorded north of Oulu. From them 7 species (Chlorops troglodytes Zetterstedt, C. rufinus Zetterstedt, C. gracilis Meigen, C. brevimanus Loew, C. scalaris Meigen, $C$. zonulatus Wahlgren, and Thauma-tomyia notata) do not cross the Arctic Circle. Only 14 species are recorded north of the Arctic Circle: Cetema cereris, Chlorops varsoviensis Becker, Thaumatomyia hallandica, T. glabra, T. trifasciata, Chlorops planifrons Loew, C. rossicus Smirnov, C. speciosus Meigen, C. rufescens Oldenberg, C. scutellaris Zetterstedt, Melanum laterale Haliday, Epichlorops puncticollis Zetterstedt, Meromyza saltatrix L. Pseudo-pachychaeta ruficeps. Only the last 11 and above species are recorded on the Kola Peninsula up to the sea shore of the Arctic Ocean.

The Finnish fauna of the genus Meromyza Meigen and the tribe Chloropini were compared earlier with the known fauna of the respective groups in Yakutia (Nartshuk, 1988, 1992e, 1998). The territory of Yakutia lies nearly on the same latitude, but in a strongly continental sector of Eurasia. A comparison of the fauna of all genera of Chloropinae of these two territories leads to the following conclusions.

1.The Finnish fauna of Chloropinae is richer than that of Yakutia: 67 and 51 recorded species respectively (see Table 1).

2. The fauna of Yakutia contains more xerophilous elements, especially in the genera Meromyza Meigen and Lasiosina Becker.

3. More species cross the Arctic Circle northwards in Yakutia than in Finland: 21 and 11 species respectively.

4. The number of species in common is not high: 30 species $(34.5 \%)$, and these species are common Holarctic and transpalaearctic species with one exception. It is Chlorops scutellaris
Zetterstedt, a species of probably Siberian origin (see Nartshuk, 1998).

The maps include records not only from Finland, Karelia and the Kola Peninsula, but also from the Karelian Isthmus and Solovetstk Islands.

Acknowledgments. The work was fulfilled with the financial support of the Russian Foundation of Fundamental Research (grants 99-04-49809 4 and 95-15-97910) and the Federal Special Science and Technology Programme "Biological Diversity". I wish to express my sincere thanks to the Finnish entomologists Dr. W. Hackman, Dr. G. Ståhls, Dr. P. Vilkamaa, Dr. H. Silfverberg for valuable help during my visits to the Zoological Museum in Helsinki for work on the Project 20 and Dr. M. Koponen for some Finnish Chloropidae. My sincere thanks to Dr. J.W. Ismay (University Museum of Natural History, Oxford, UK) for correcting the English of the text.

\section{References}

Andersson, H. 1977: Taxonomic and phylogenetic studies on Chloropidae (Diptera) with special reference to Old World genera. - Entomol. Scand. Suppl. 8: 1-200.

Beschovski, V. \& Krustena, H. 1997: Contribution to the study of the pupa and biology of Lasiosina brevisurstylata and L. cinctipes (Insecta, Diptera, Chloropidae). - Acta zool. Bulgarica 49: 32-41.

Frey, R, 1933: Förteckung över Finlands chloropider, bestämda av. O. Duda. - Mem. Soc. Fauna Flora Fennica 9: 128-139.

Hackman, W. 1980: A check list of the Finnish Diptera II Cyclorrhapha. - Notulae Entomol. 60: 117-162.

Kallio, A. 1950: Some new insect pest of cereals in Finland. - Ann. Entomol. fennici 16: 200-201.

Kontkanen, P. 1935: Trichieurina pubescens Meig. (Dipt., Chloropidae) in Finnland gefunden. - Ann. Entomol. fennici 10(2): $60-62$.

Krogerus, R. 1932: Über die Ökologie und verbreitung der Arthropoden der Tiebsandgebiete an den Kusten Finlands. - Acta Zool. Fennica 12: 1-308.

Krogerus, R. 1960: Ökologische Studien über nordische Moorarthropoden. - Comment. Biol. 21(3): 1-238.

Laaksonen, K. 1979: Effective temperature sums and duration of the vegetative period in Fennoscandia (19211950). - Fennia 157: 171-197.

Lindberg, H. \& Saris, N. E. 1952: Insektenfaunan i Pisavaara naturpark (Finland, Prob. Ob.). - Acta Soc. Fauna Flora Fennica. 69(2): 1-82.

Nartshuk, E. P. 1962: (On fauna and ecology of Chloropidac (Diptera) of Leningrad oblast). - Trudy Zool. Inst. Acad. Sci. of USSR. 30: 250-275. (In Russian)

Nartshuk, E.P. 1984: (Diptera of Bolshoy Beresovyy Islands connected with grasses with description of a new species of the family Opomyzidae). - Trudy Zool. Inst. Acad. Sci. of USSR, Leningrad. 23: 51-59. (In Russian) 
Nartshuk, E. P. 1988: (Chloropid-flies of the genus Meromyza Mg. (Diptera, Chloropidae) from Finland). - The connections between entomofaunas of the North Europe and Siberia. Leningrad: 112-117. (In Russian)

Nartshuk, E. P. 1992a: (On grassflies (Diptera, Chloropidae) of Ukraine). - The $3 \mathrm{~d}$ meeting of the Ukrainian entomol. soc. Kharkov: 114-115. (In Ukrainian)

Nartshuk, E. P.1992b: (Chloropid flies of the genus Chlorops (Diptera, Chloropidae) of Yakutia). - Systematica, zoogeografia i karyologia dvukrylykh nasekomykh. St. Petersburg: 121-129. (In Russian)

Nartshuk, E. P. 1992c: Revision of the species of Meromyza Meigen (Diptera, Chloropidae) from Finland. - Entomol. Fennica 3(3): 121-138.

Nartshuk, E. P. 1997: Grassflies of the subfamily Chloropinae (Diptera, Chloropidae) of Yakutia and Magadan province. - Intern. J. Dipterol. Research 8(1): 9-22.

Nartshuk, E.P. 1998: A revision of the tribe Chloropini (Diptera, Chloropidae) from Finland, Karelia and North-
West Russia. — Entomol. Fennica 9(3): 153-183.

Nartshuk, E. P. \& Elberg, K. 1979: (List of Chloropidae (Diptera) of Estonia. - Dipteroloogilisi Uurimus. Tartu: 122143. (In Russian, English and Estonian summaries)

Nartshuk, E.P. \& Fedoseeva, L.I. 1980: (On fauna of Yakutian steppe: grassflies of the genus Meromyza Mg. (Diptera, Chloropidae)). - Biol. nauki, Moskwa 9: 46-52. (In Russian).

Séguy, E. 1934: Chloropidae. - Fauna de France. Paris. 28. Diptères: 472-537.

Stackelberg, A. A. 1958: (Materials on Diptera fauna of Leningrad oblast. III Diptera Acalyptratae. pt. 1). - Trudy Zool. Inst. Acad. Sci. of USSR. Leningrad. 24:103-191. (In Russian)

Stackelberg, A. A. 1965: (New data on Diptera fauna of Leningrad oblast), - Latvias Entomologs. 10: 61-71. (In Russian) 
Table 1. List of Chloropinae species known from Finland, Estonia, North-Western Russia with their occurence in Yakutia

\begin{tabular}{|c|c|c|c|c|c|c|c|}
\hline Species & ZE & Fin & Est & $\mathrm{SPb}$ & $\mathrm{Kr}$ & $\mathrm{Lr}$ & Ya \\
\hline Platycephala planifrons & EAt & + & + & + & + & - & - \\
\hline P. umbraculata & $\mathrm{TPp}$ & + & ex & + & + & - & $=$ \\
\hline Trichieurina pubescens & $E A b$ & + & ex & + & ex & - & ex \\
\hline Cryptonevra diadema & EAt & + & + & + & - & - & - \\
\hline C. flavitarsis & EAt & + & + & + & ex & - & - \\
\hline Neohaplegis tarsata & $\mathrm{TPb}$ & + & + & + & + & - & + \\
\hline Cetema cereris & $\mathrm{TPp}$ & + & + & + & + & - & + \\
\hline C. elongatum & $E$ & + & + & + & - & - & - \\
\hline C. myopinum & EAp & + & + & + & + & - & - \\
\hline C. neglectum & $E$ & + & ex & ex & - & $=$ & $=$ \\
\hline C. simile & $E$ & + & + & + & + & - & - \\
\hline Thaumatomyia glabra & $\mathrm{H}$ & + & + & + & + & + & + \\
\hline T. hallandica & Tpb & + & + & + & + & - & + \\
\hline T. notata & TPp & + & + & + & + & - & + \\
\hline T. rufa & $\mathrm{TPp}$ & + & + & + & + & $\cdot$ & + \\
\hline T. trifasciata & $\mathrm{H}$ & + & + & + & + & + & + \\
\hline Eutropha variegata & EM & + & + & + & - & - & - \\
\hline E. fulvifrons & EM & + & ex & $=$ & - & - & - \\
\hline Centorisoma elegantulum & Eat & ex & + & + & ex & - & $=$ \\
\hline Diplotoxa messoria & $\mathrm{H}$ & + & + & + & + & - & + \\
\hline $\begin{array}{l}\text { Diplotoxoides dalmatinus } \\
\text { Pseudopachychaeta }\end{array}$ & $\mathrm{TPb}$ & + & ex & + & + & - & + \\
\hline approximatonervis & $\mathrm{H}$ & + & + & + & + & - & + \\
\hline P. ruficeps & $\mathrm{TPb}$ & + & + & + & + & + & + \\
\hline P. heleocharis & $\mathrm{EK}++$ & + ex - & - & & & & \\
\hline Lasiosina albipila & $\mathrm{TPp}$ & + & + & + & ex & - & - \\
\hline L. brevisurstylata & Eat & + & ex & + & ex & - & + \\
\hline L. herpini & $\mathrm{TPp}$ & + & + & + & + & - & + \\
\hline L. parvipennis & $\mathrm{TPb}$ & + & + & + & Ex & - & ex \\
\hline Meromyza, Nartshuk, 1992 & & 16 & 16 & 14 & 12 & 2 & 17 \\
\hline Chloropini, Nartshuk, 1998 & & 24 & 29 & 29 & 21 & 8 & 17 \\
\hline Total & & 67 & 68 & 69 & 50 & 13 & 51 \\
\hline
\end{tabular}

Note. ex - expected species. Data on the occurence in Yakutia (Nartshuk, 1992b, 1997, Nartshuk \& Fedoseeva, 1980 ) are added for comparison and do not represent a complete list for this territory. The total number of species of Chloropinae recorded from Yakutia is 51.

ZE - zoogeographical elements: E - european, EAb- euro-asian boreal, EAt - euro-asian temperate, EC - eurocaucasian, EM - euro-mediterranean, EK - euro-kazakhstanian, $\mathrm{H}$ - Holarctic, TPb - transpalaearctic boreal, TPp transpalaearctic polyzonal. TPt - transpalaearctic temperate. 


\section{Appendix}
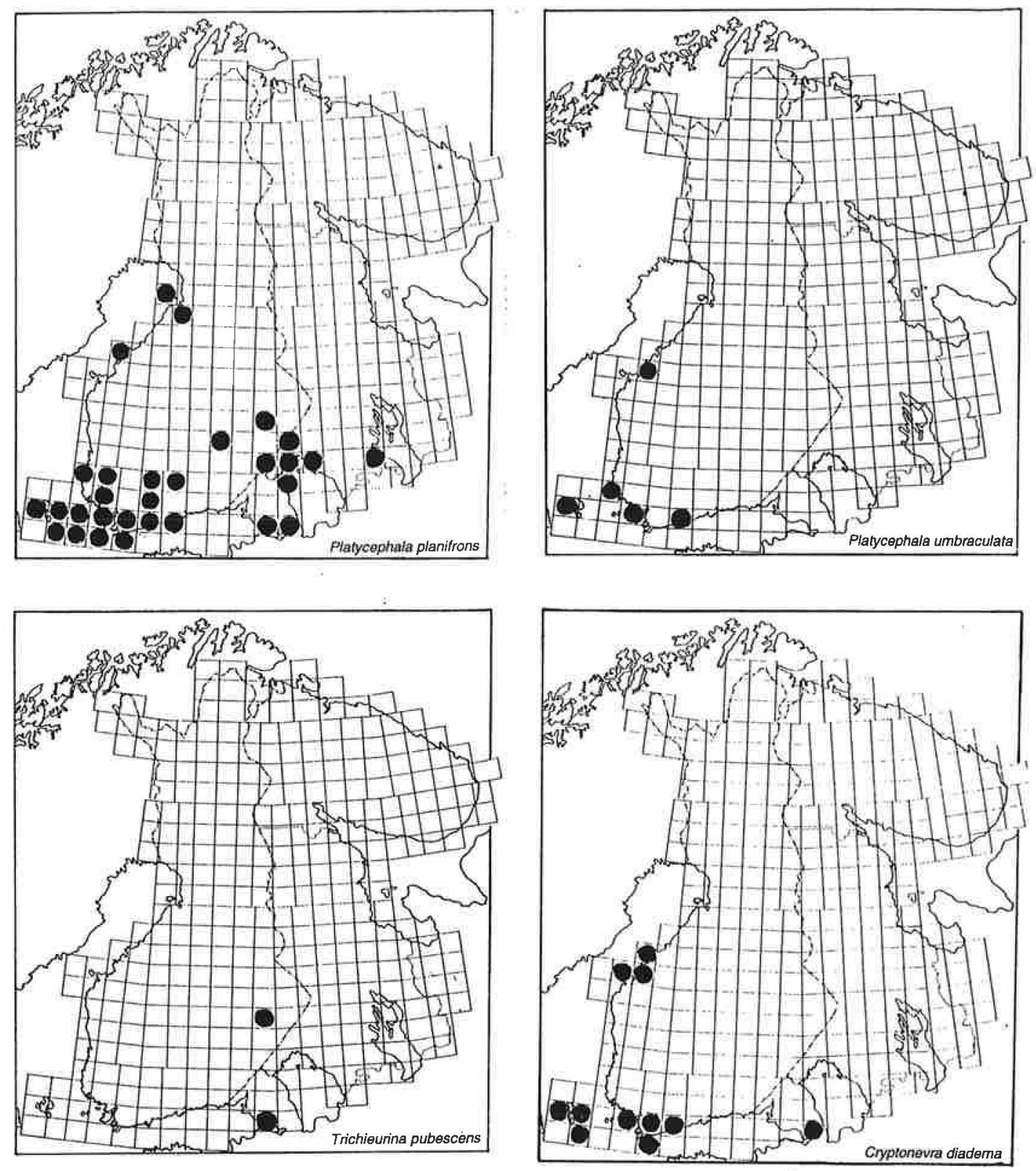

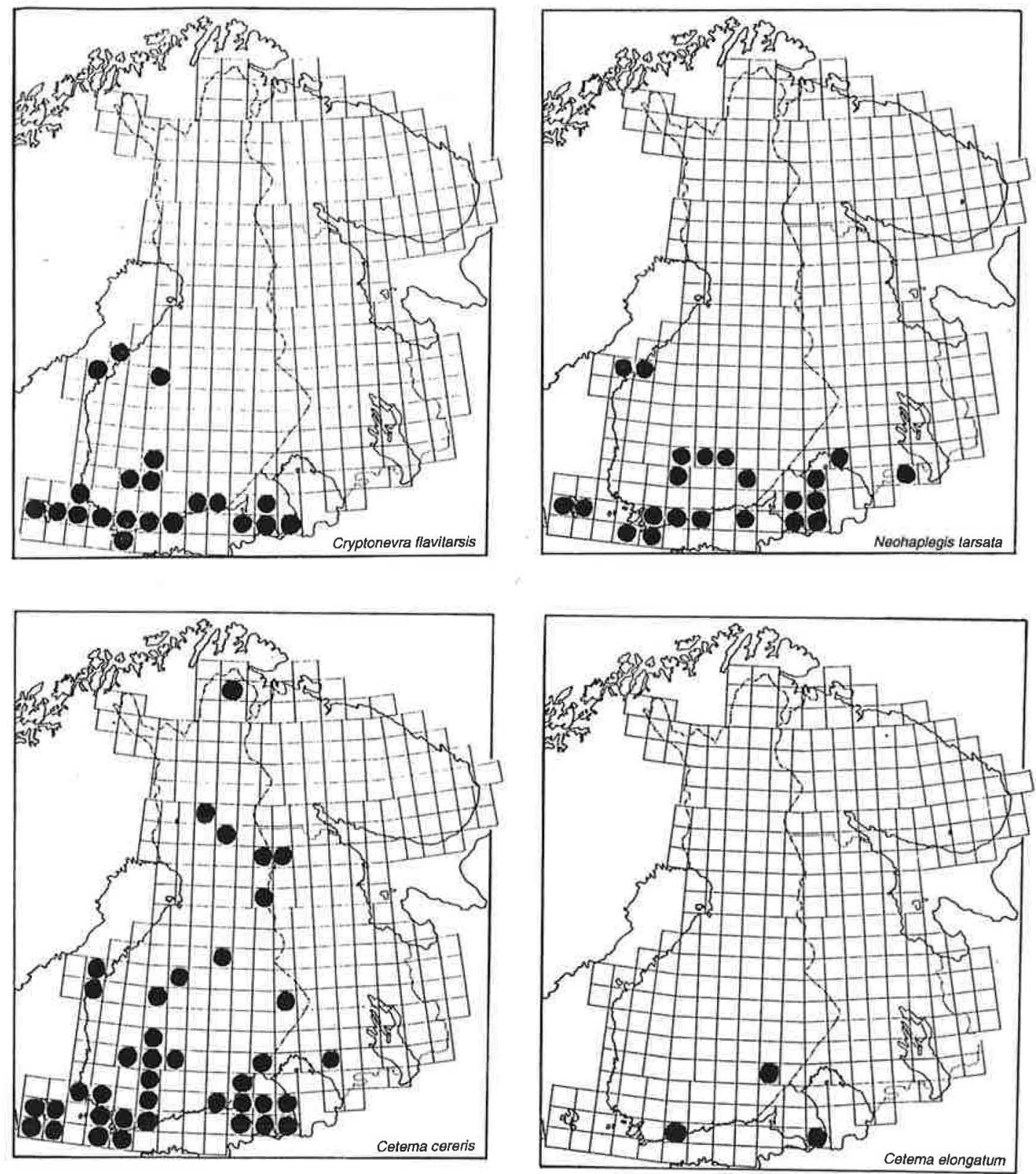



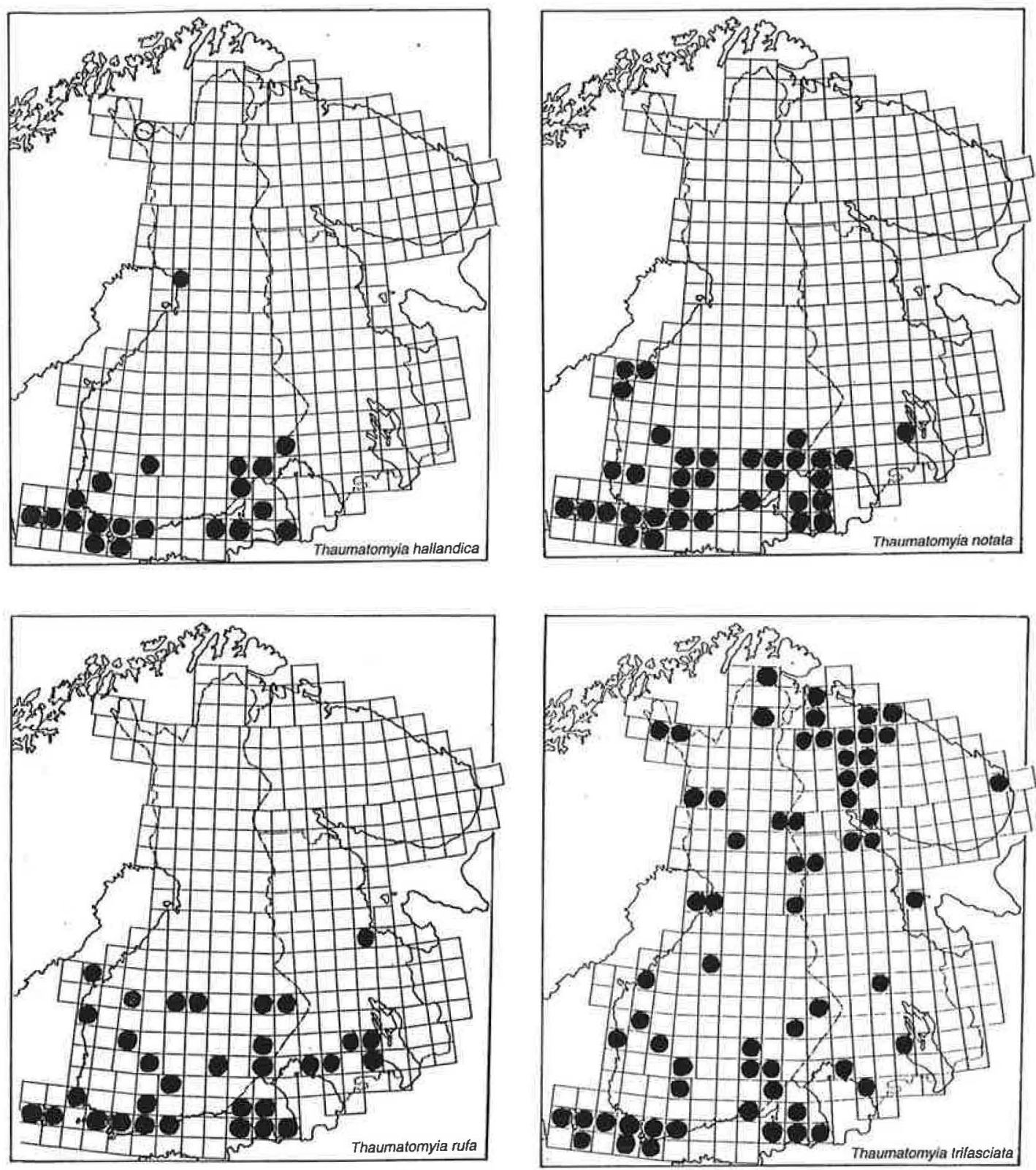

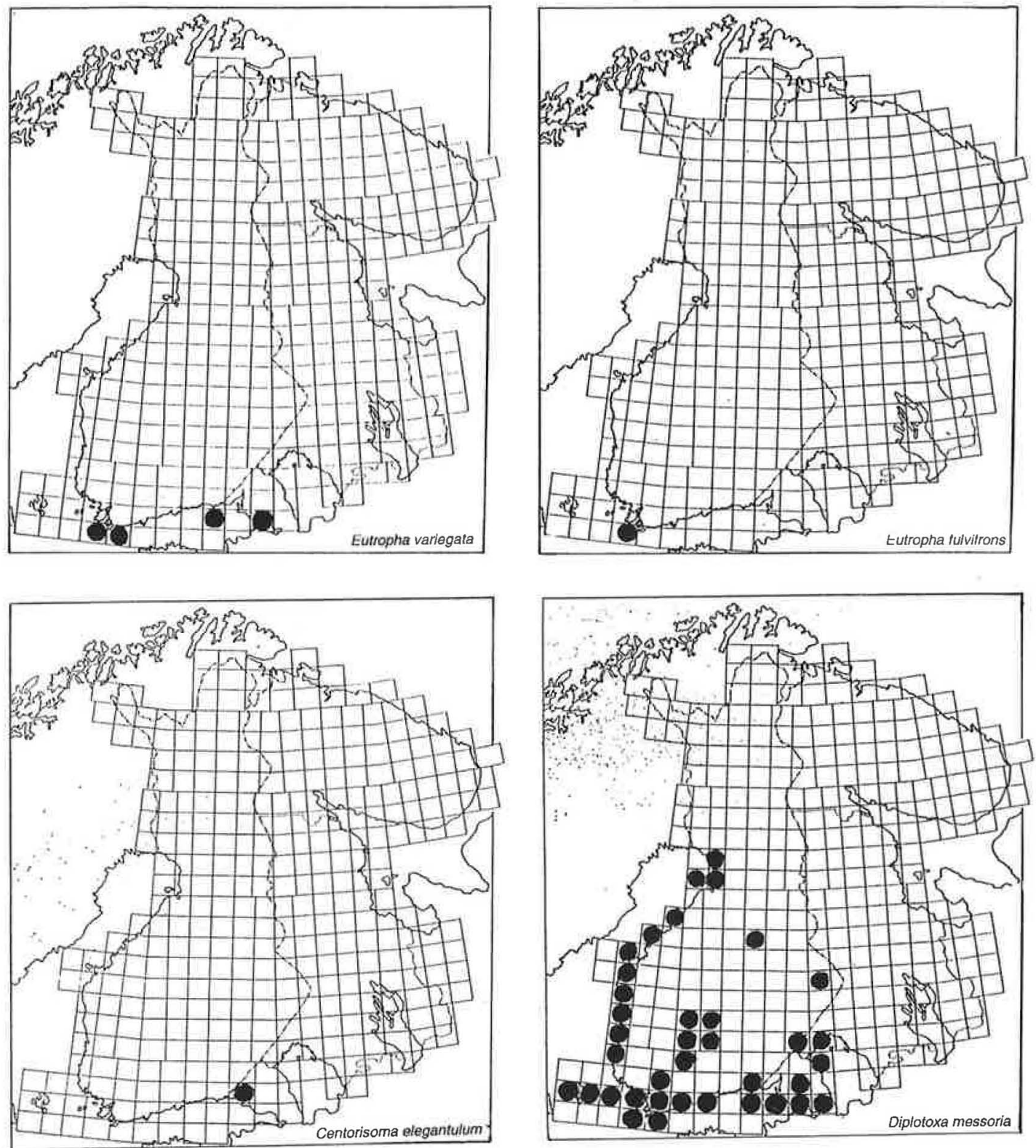

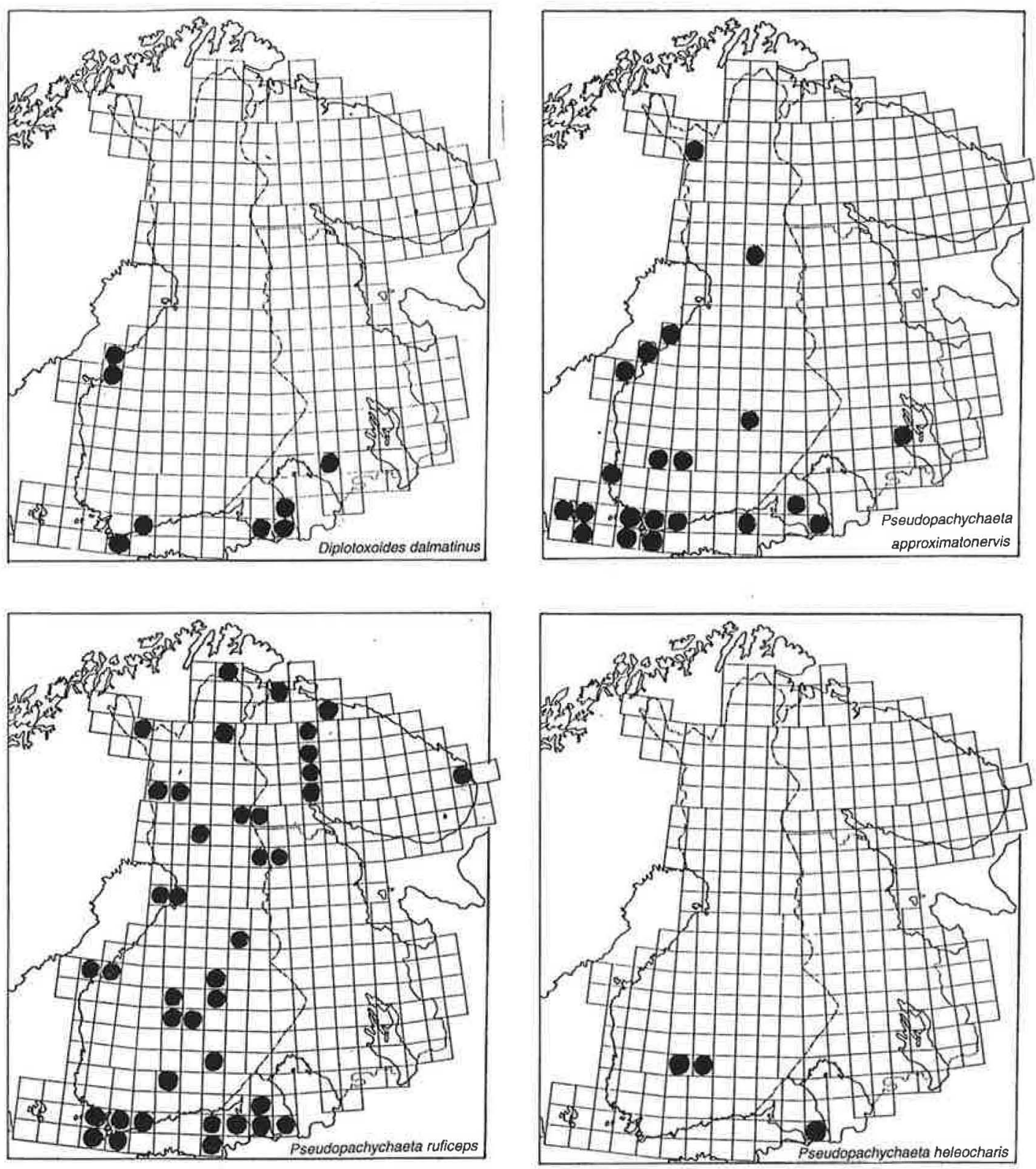

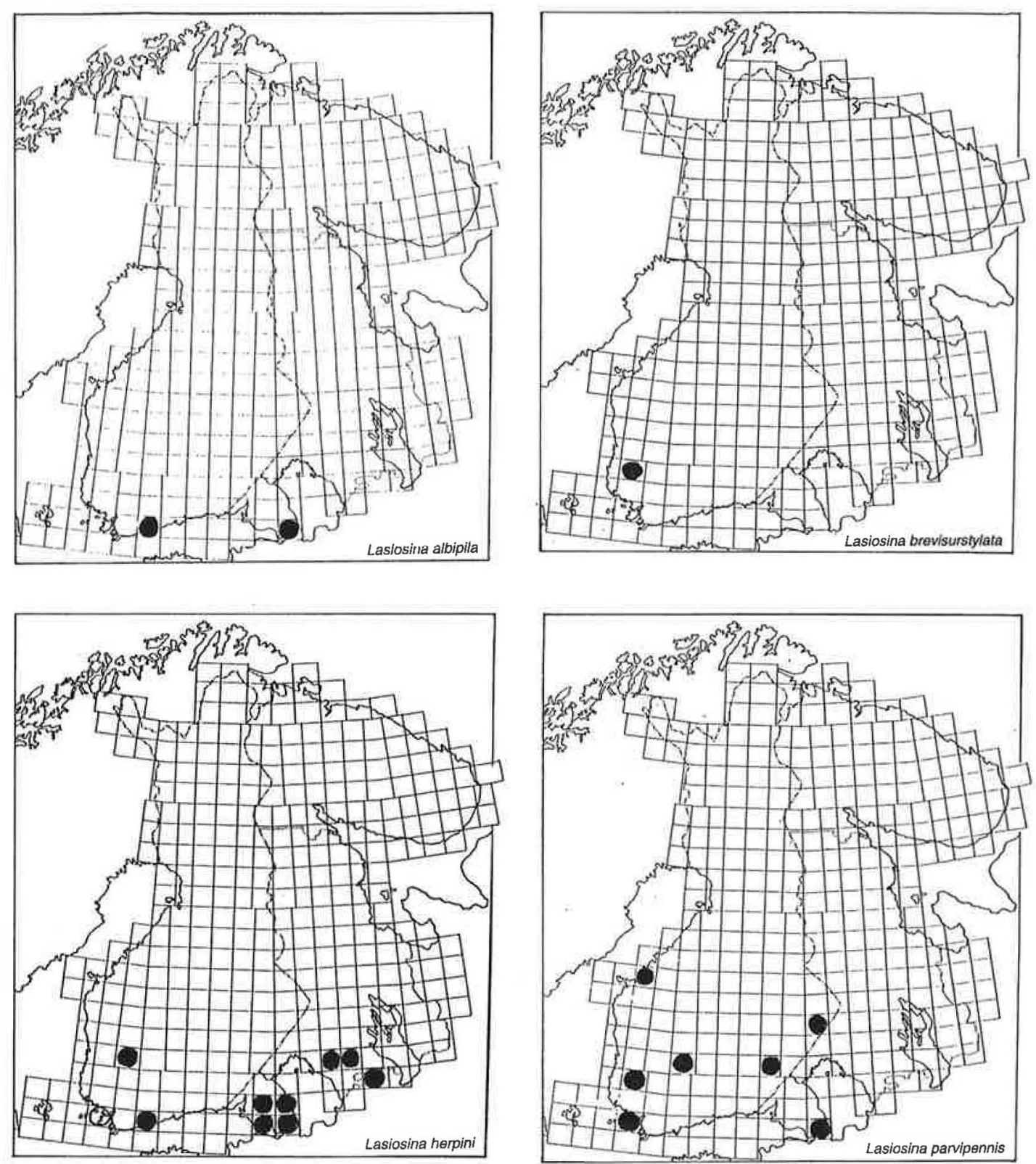